\title{
Morphophysiological, Enzymatic, and Elemental Activity in Greenhouse Tomato Saladette Seedlings from the Effect of Plant Growth-Promoting Rhizobacteria
}

\author{
Tomás Juan Álvaro Cervantes-Vázquez ${ }^{1}$, Ana Alejandra Valenzuela-García ${ }^{1}$, María Gabriela Cervantes-Vázquez ${ }^{1}$, \\ Tania Lizzeth Guzmán-Silos ${ }^{2}$, Erika Lagunes Fortiz ${ }^{3, *}$, Pablo Preciado Rangel ${ }^{4}$ and Edgar Omar Rueda-Puente ${ }^{5, *} \mathbb{(}$ \\ 1 Facultad de Agricultura y Zootecnia, Universidad Juárez del Estado de Durango, \\ Venecia 34000, Durango, Mexico; alvaro87tomas@hotmail.com (T.J.Á.C.-V.); \\ ale.valenzuela@ujed.mx (A.A.V.-G.); cevga@hotmail.com (M.G.C.-V.) \\ 2 Departamento de Investigación y Desarrollo Tecnológico, Ingeniería en Biotecnología. Universidad \\ Politécnica de Gómez Palacio, Gómez Palacio 35120, Durango, Mexico; tanializguzman@hotmail.com \\ 3 Departamento de Fitotecnia, Universidad Autónoma Chapingo, Carretera Mexico-texcoco km 38.5 Chapingo, \\ Texcoco 56230, Edo de Mexico, Mexico \\ 4 Tecnológico Nacional de México—Campus Instituto Tecnológico de Torreón (TecNm—ITT), Antigua \\ Carretera Torreón-San Pedro km 7.5, Torreón 27170, Coahuila, Mexico; ppreciador@yahoo.com.mx \\ check for \\ updates \\ Citation: Cervantes-Vázquez, T.J.Á.; \\ Valenzuela-García, A.A.; \\ 5 Departamento de Agricultura y Ganadería, Universidad de Sonora, Bulevard Luis Encinas y Rosales s/n, \\ Colonia Centro, Hermosillo 83000, Sonora, Mexico \\ * Correspondence: erika_lagunes@hotmail.com (E.L.F.); erueda04@santana.uson.mx (E.O.R.-P.); \\ Tel.: +52-1-641-327-0764 (E.O.R.-P.)
}

Cervantes-Vázquez, M.G.; Guzmán-Silos, T.L.; Fortiz, E.L.; Rangel, P.P.; Rueda-Puente, E.O. Morphophysiological, Enzymatic, and Elemental Activity in Greenhouse Tomato Saladette Seedlings from the Effect of Plant Growth-Promoting Rhizobacteria Agronomy 2021, 11, 1008. https:// doi.org/10.3390/agronomy11051008

Academic Editors: José M. De la Rosa, Marina Paneque and David Houben

Received: 18 March 2021

Accepted: 17 May 2021

Published: 20 May 2021

Publisher's Note: MDPI stays neutral with regard to jurisdictional claims in published maps and institutional affiliations.

Copyright: (c) 2021 by the authors. Licensee MDPI, Basel, Switzerland. This article is an open access article distributed under the terms and conditions of the Creative Commons Attribution (CC BY) license (https:// creativecommons.org/licenses/by/ $4.0 /)$.
Abstract: The tomato is a widely cultivated and consumed vegetable globally. Comarca Lagunera is an important tomato-exporting region of Mexico. Salinity is an abiotic factor that reduces productivity and increases production costs. To advance growing period, there is high demand for the sustainable production of seedlings. Plant-growth-promoting rhizobacteria (PGPR) are characterized by improving plant growth through different mechanisms and can be an option for reducing the misuse of chemical fertilizers. The importance of the application of strains, evaluating various inoculation methods (in seed, soil, foliar spraying, and root immersion), should be evaluated to propose biofertilization packages in a specific crop. Thus, the study aimed to determine the effect of PGPR (Bacillus paralicheniformis, Acinetobacter guillouiae, Aeromonas caviae, and Pseudomonas lini) vs. nutrient solution and distilled water in the seedlings stage of saladette-type tomato on morphophysiological variables, nitrate reductase (NR) enzyme activity, and plant minerals via tissue analysis under greenhouse conditions. The four PGPR were inoculated by different methods (inoculation in seed, sprinkling, and both) in saladette-type tomato seedlings under greenhouse conditions and evaluated in vivo 40 days after sowing for morphophysiological variables, such as seedling height; stem diameter; root displaced volume; fresh and dry weight matter of the leaves, stems, and roots; leaf area; and nitrate reductase enzyme activity. The effect of the inoculation of PGPR showed significant results for Pseudomonas lini vs. the control, with $40 \%$ higher values, on average, for plant height, stem diameter, displaced root volume, and fresh weight of root, leaf, and stem. The response of enzymatic and mineral content in seedlings was variable with nutrient solution and significant with distilled water. Studies related to the promotion of plants in the subsequent phenological stages of a tomato, considering the selected PGPR, should be considered in future research.

Keywords: biofertilizer; growth promoters; sprinkled; inoculants

\section{Introduction}

Tomato (Solanum lycopersicum) is a widely cultivated and consumed vegetable, with global production of 243,635,433 t. In 2019, the main producer was China, with 125,739,004t produced, and Mexico ranked tenth, with a production of 3,441,639 $\mathrm{t}$ [1]. At the state level, 
in 2019, Coahuila, Mexico, produced 121,579 t, with a value of MXN 816 million. In the Comarca Lagunera region, there are 1090 ha of greenhouses and shade houses for tomato production, generating a harvest of $145,769 \mathrm{t}$, with a yield of $135 \mathrm{t} \mathrm{ha}^{-1}$ and a production value of MXN 911,369,000 [2]. Nurserymen, who produce seedlings under special conditions, are an important sector in the total tomato production system, advancing sowing dates, and reducing production costs and environmental impacts [3]. Thus, they make the marketing windows effective. However, these nurserymen need to produce the seedlings in sustainable conditions, since the farmers who will acquire these plants must adhere to a production system in the field or in a greenhouse that uses ecological alternatives. This need to demand seedlings developed with sustainable tools is not only to introduce them to an organic production system; the soils of the Comarca Lagunera region present high salinities that, with the application of chemical fertilizers, exacerbate the problem of salinity. In this sense, the provision of seedlings through organic alternatives allows the use of biofertilization as an ecological and sustainable tool [4]. One alternative for biofertilization is based on plant-growth-promoting rhizobacteria (PGPR). Some rhizobacteria, as part of their metabolism, increase fertility and benefit plants; crop growth can be affected by mechanisms such as phosphate solubilization, phytohormone production, antibiotics, and other vegetative biostimulant compounds [5]. There are already some commercial rhizobacteria that the tomato seedling producer has turned to. However, because these rhizobacteria are isolated from different environments (not saline and good temperature), these microorganisms have not been effective in extreme environments, such as the Comarca Lagunera region. Therefore, there is a need to enlarge the knowledge of other microorganisms that adapt to edaphoclimatic conditions and can be used as future biofertilizers in extreme environments [6].

Research carried out by Lara et al. [7] indicates the importance of the application of native strains, showing that plant material inoculated with a native strain presents higher average heights, lengths of leaves, and notable vegetative development in the angleton grass plant (Dichantium aristatum Benth). Similarly, in addition to expanding the range of PGPR that can be obtained from a particular area, several inoculation methods can be used, particularly inoculation of the seed, soaking of the soil, foliar spray, and immersion of the root. The inoculation method for these new PGPR should be evaluated, not only to propose indigenous PGPR, but also to promote them with their respective inoculation method in a particular crop [8].

Based on the above discussion, the objective of this study aimed to determine the effect of PGPR (Bacillus paralicheniformis, Acinetobacter guillouiae, Aeromonas caviae, and Pseudomonas lini) in the seedlings stage of saladette-type tomato on morphophysiological variables, nitrate reductase (NR) enzyme activity, and plant minerals via tissue analysis under greenhouse conditions.

\section{Materials and Methods}

\subsection{Inoculation in Seed and Production of Seedlings}

The inoculation study of tomato seedlings was carried out under greenhouse conditions at the Technological Institute of Torreon, located between coordinates $24^{\circ} 30^{\prime}$ and $27^{\circ} \mathrm{N}$, and $102^{\circ} 00^{\prime}$ and $104^{\circ} 40^{\prime} \mathrm{W}$, at an altitude of 1120 masl (meters above sea level). The vegetative material of tomato corresponds to the hybrid saladette type cv. Sahel, which is an indeterminate hybrid with a robust plant that produces high yields. The hybrid produces uniform fruits of good quality, with soft shoulders, shine, and firmness throughout the season, even in adverse conditions. Extra-large to large fruit are of intermediate maturity, and are ideal for national and export markets [9].

The treatments under study were designed from the combination of inoculation with four bacterial strains (LB1 = Bacillus paralicheniformis; NFB2 = Acinetobacter guillouiae; KB3 = Aeromonas caviae $; \mathrm{KB} 4=$ Pseudomonas lini) considering three methods of application (seedling spray (AP), seed inoculation (IS), and both (AP + IS) and two controls (distilled water and a nutritive solution) applied under irrigation mode, resulting in a total of 
14 treatments, as described in Table 1 . The distribution design of the resulting treatments was still completely random, with eight replications obtaining 120 experimental units. The four bacterial strains were donated by the microbial ecology laboratory from Universidad Juarez del Estado de Durango (UJED).

Table 1. Halo-PGPR, and mode of application used in the production of tomato seedlings.

\begin{tabular}{cccc}
\hline \multicolumn{2}{c}{ Treatments } & $\begin{array}{c}\text { Bacteria } \\
\mathbf{1} \times \mathbf{1 0}^{\mathbf{8}} \mathbf{C F U}\end{array}$ & Mode of Application \\
\hline 1 & B. paralicheniformis & LB1 & Seed Inoculation (IS) \\
2 & B. paralicheniformis & LB1 & Seedling Spray (AP) \\
3 & B. paralicheniformis & LB1 & Both (AP + IS) \\
4 & A. guillouiae & NFB2 & Seed Inoculation (IS) \\
5 & A. guillouiae & NFB2 & Seedling Spray (AP) \\
6 & A. guillouiae & NFB2 & Both (AP + IS) \\
7 & A. caviae & KB3 & Seed Inoculation (IS) \\
8 & A. caviae & KB3 & Seedling Spray (AP) \\
9 & A. caviae & KB3 & Both (AP + IS) \\
10 & P. lini & KB4 & Seed Inoculation (IS) \\
11 & P. lini & KB4 & Seedling Spray (AP) \\
12 & P. lini & KB4 & Both (AP + IS) \\
13 & Distilled water & DW & Irrigation \\
14 & Nutritive solution & NS & Irrigation \\
\hline
\end{tabular}

CFU: colony-forming unit. LB1 = Bacillus paralicheniformis; NFB2 = Acinetobacter guillouiae; KB3 = Aeromonas caviae; $\mathrm{KB} 4=$ Pseudomonas lini; $\mathrm{DW}=$ distilled water; $\mathrm{NS}=$ nutritive solution .

After the reactivation of each bacterial strain, it was adjusted to a concentration of $1 \times 10^{8} \mathrm{CFU}$ in $0.5 \%$ PBS. For seed inoculation, 200 tomato seeds were added to each of the bacterial cultures in a $50 \mathrm{~mL}$ Kitazato flask, and they were vacuum subjected to $600 \mathrm{~mm} \mathrm{Hg}$ for $5 \mathrm{~m}$ [10]. Then, the seeds inoculated by vacuum infiltration of the bacteria were deposited in germinating plates of $1 \mathrm{~m}^{2}$ containing $7 \mathrm{~cm}$ of peat moss (brand PROMIX GTX; base of fine granulation sphagnum peat of Canadian origin) as the medium of germination, and covered with black plastic until germination. The germinating plates were placed in a greenhouse at an ambient temperature of $27^{\circ} \mathrm{C}$ and a relative humidity of $35 \%$. After emergence, the trays were conditioned at $12 \mathrm{~h}$ light/dark. Irrigation with distilled water was carried out daily until 40 days after sowing (DAS).

Regarding the spray application [11], each bacterial strain was adjusted to a concentration of $1 \times 10^{8} \mathrm{CFU}$ in $0.5 \%$ PBS. Every eight days, aspersions were carried out until 40 DAS, covering $300 \mathrm{~mL}$ per plant with the bacterial strain under study. Treatment of the union of both types of inoculation (AP + IS) was the same as that indicated previously.

\subsection{Irrigation and Preparation of Nutrient Solution}

Irrigation with distilled water was applied to each tray to attribute the results to the evaluated treatments; half of the volume was applied in the morning and the remainder in the afternoon to maintain the seedlings in optimal humidity conditions. The water from Lagunera Comarca is rich in minerals; according to the classification of water for agricultural irrigation in Manual 60 of the US Department of Agriculture [12], the water is classified C2S1 of medium salinity [13]. In this sense, farmers usually apply a nutrient solution to avoid stress in the seedling stage. So, the chemical fertilization in this study was considered as a control, using a Steiner nutrient solution (Table 2) and applying in a volume of $1 \mathrm{~L}$ per day for all seedlings throughout the experiment. Distilled water was considered the other treatment control. 
Table 2. Chemical composition of Steiner solution.

\begin{tabular}{|c|c|c|c|c|c|c|}
\hline & $\mathrm{NO}_{3}{ }^{-}$ & $\mathrm{H}_{2} \mathrm{PO}_{4}^{-}$ & $\mathbf{K}^{+}$ & $\mathrm{Ca}^{2+}$ & $\mathrm{Mg}^{2+}$ & $\mathrm{SO}_{4}^{-}$ \\
\hline & \multicolumn{6}{|c|}{ Percentage Ratio in $\mathrm{mol} \mathrm{m}$} \\
\hline Solution Steiner & 12 & 1 & 7 & 9 & 4 & 7 \\
\hline water & & & 0.17 & 1.36 & 0.24 & 0.23 \\
\hline
\end{tabular}

\subsection{Variables Evaluated In Vivo in Greenhouse Tomato Seedlings}

2.3.1. Seedling Height; Stem Diameter; Root Displaced Volume; Fresh and Dry Weight (Dry Matter) of Leaves, Stem, and Root; Leaf Area

Seedling height was measured at the conclusion of the experiment at 40 DAS, based on eight repetitions per treatment. A STANLEY (USA) $8 \mathrm{~m} / 26^{\prime}$ tape measure was used, and the data for this variable are expressed in centimeters $(\mathrm{cm})$. The stem diameter was measured using a metric and imperial scale Starrett 1223 (USA) Special Master Dial Indicator analog vernier, and the data for this variable are expressed in millimeters $(\mathrm{mm})$. For the root displaced volume variable, a graduated cylinder was used as a level, after which the root was submerged and the volume of the root inside the cylinder was quantified; the data for this variable are expressed in milliliters $(\mathrm{mL})$. Seedling fresh and dry weight (dry matter) of leaves, stem, and root, and leaf area were quantified once at the end of the experimental work; a VELAB VE-500 (USA) digital analytical balance was used, and the results obtained are expressed in grams (g). Dry matter was quantified at the end of the experimental work. The vegetative material was previously dried for $72 \mathrm{~h}$ in a drying oven at a temperature of $80^{\circ} \mathrm{C}$, and then weighed on a VELAB VE-500 (USA) digital analytical balance; the results for this variable are expressed in grams (g). Leaf area was obtained once at the end of the experiment. A foliar area integrator of brand LI-COR and model LI-3100 (USA) was used, and the results reported for this variable are expressed in $\mathrm{cm}^{2}$.

\subsubsection{Enzymatic Activity}

Nitrate reductase enzyme activity in vivo was assessed at the end of 40 DAS. Tomato seedling samples were collected and taken in containers with ice to avoid early wilting to the Laboratory of Plant Physiology and Nutrition of the Center for Research in Food and Development (CIAD) Delicias Unit, Chihuahua, for determination. The procedure used was an adaptation of the methods proposed by Joworski [14] and Mauriño [15]. The test was carried out both on the leaf blade and the root of the plant. Three enzymatic activities of nitrate reductase were tested: (1) endogenous reaction; (2) induced reaction with $\mathrm{NO}_{3}{ }^{-}$substrate; and (3) reaction with Mo as a cofactor. For the quantification of NR activity in vivo, $0.15 \mathrm{~g}$ of leaves and stem were weighed. Leaf discs were generated with a punch and introduced into $10 \mathrm{~mL}$ of infiltration medium, which was different depending on the determined NR activity: (a) in the case of endogenous NR activity, $10 \mathrm{~mL}$ of $100 \mathrm{mM}$ potassium phosphate buffer $\mathrm{pH} 7.5$ was used plus 1\% propanol; (b) for NR activity induced with $\mathrm{NO}_{3}{ }^{-}, 10 \mathrm{~mL}$ of potassium phosphate buffer $100 \mathrm{mM} \mathrm{pH} 7.5$, containing $50 \mathrm{mM}$ potassium nitrate plus $1 \%$ propanol was considered; (c) for NR activity induced with molybdate, $10 \mathrm{~mL}$ of potassium phosphate buffer $100 \mathrm{mM} \mathrm{pH} 7.5$ was applied, containing $50 \mathrm{mM}$ sodium molybdate dihydrate plus $1 \%$ propanol. Then, for each of the analyses separately, the samples were subjected to a vacuum process ( 8 bar) for $10 \mathrm{~min}$ in the dark; the samples were subsequently incubated at $30^{\circ} \mathrm{C}$ in the dark for $60 \mathrm{~min}$. The tubes were placed in a hot water bath at $100{ }^{\circ} \mathrm{C}$ for $15 \mathrm{~min}$. For the determination of NR activity in vivo, the following were used: $1 \mathrm{~mL}$ of the aliquot (Metra); $2 \mathrm{~mL}$ of $1 \%$ sulfanilamide dissolved in 1.5 normal HCl; $1 \mathrm{~g}$ of sulfanilamide plus $20 \mathrm{~mL}$ of $35 \% \mathrm{HCl}$, dissolved in $100 \mathrm{~mL}$ of water; $2 \mathrm{~mL}$ of N-1-naphthyl-ethylenediamide (NNEDA) at $0.02 \%$, dissolved in 0.2 normal $\mathrm{HCl}$; and $20 \mathrm{mg}$ of NNEDA dissolved in $100 \mathrm{~mL}$ of $\mathrm{HCl}$, in this case water. After $20 \mathrm{~min}$, the absorbance was read using a Jenway EW-83058-18 (UK) UV/Vis spectrophotometer at a wavelength of $540 \mathrm{~nm}$, against a standard curve of $\mathrm{NO}_{2}{ }^{-}$between 0.25 and $2 \mu \mathrm{g} \mathrm{ml}^{-1}$, following the method proposed by Hageman and Hucklesby [16]. The nitrate reductase 
activity in vivo was expressed in $\mu \mathrm{M}$ of $\mathrm{NO}_{2}{ }^{-}$formed by $\mathrm{g}^{-1} \mathrm{p} . \mathrm{F} \cdot \mathrm{h}^{-1}$ (micromoles of nitrites formed by grams of fresh weight in one hour).

\subsubsection{Plant Tissue Elemental Analysis}

Samples of fresh tomato seedlings were collected and taken to the Laboratory of Plant Physiology and Nutrition of the Food and Development Research Center (CIAD) Delicias Unit, Chihuahua, where they were subsequently washed and dried to determine the following minerals: nitrogen $(\mathrm{N})$, phosphorus $(\mathrm{P})$, potassium $(\mathrm{K})$, calcium $(\mathrm{Ca})$, magnesium $(\mathrm{Mg})$, sodium $(\mathrm{Na})$, manganese $(\mathrm{Mn})$, nickel $(\mathrm{Ni})$, iron $(\mathrm{Fe})$, zinc $(\mathrm{Zn})$, and copper $(\mathrm{Cu})$.

For determination of the concentration of total nitrogen ( $\mathrm{Nt}$ ), $3 \mathrm{mg}$ of sample (dry and ground) of each treatment was weighed in triplicate; $11 \mathrm{mg}$ of pentoxide was added in an aluminum container and it was analyzed in a CHNS/O elemental analysis, performed using Thermo Scientific FLASH 2000 (USA) Organic Elemental Analysis (OEA) [17]. The quantification of phosphorus $(\mathrm{P})$ was undertaken using colorimetry with a mixture of triacid and metavanadate molybdate ammonium. Determination of the concentration of potassium $(\mathrm{K})$, calcium $(\mathrm{Ca})$, and magnesium $(\mathrm{Mg})$ was undertaken using atomic absorption with a digester mixture [18]. Quantification of the concentration of sodium $(\mathrm{Na})$, manganese $(\mathrm{Mn})$, nickel $(\mathrm{Ni})$, iron $(\mathrm{Fe})$, zinc $(\mathrm{Zn})$, and copper $(\mathrm{Cu})$ was undertaken using atomic absorption spectrophotometry with a digester mixture [19].

\subsubsection{Microbiological Analysis}

At the end of the experiments (40 days after sowing (DAS)), a microbiological analysis was carried out at the root and leaf level; $1 \mathrm{~g}$ of root and leaf (separately) were washed with distilled water and dilutions were made with tri-distilled water, before sowing in a Petri dish with Luria-Bertani medium lacking a nitrogen source free of nitrogen (LB) [20]. Bacterial treatments were sowed with $10^{-5}$ dilutions. After sowing, Petri dishes were incubated. Colony forming units (CFU) were monitored and quantified at $48 \mathrm{~h}$. Once the bacterial colonies were isolated, they were registered based on morphology and color, and the Rennie test.

\subsection{Experimental Design}

The data on the response variables were analyzed in a random experimental design by means of a variance analysis using the Statistical Analysis System statistical software version 9.2 (SAS Institute, Cary, NC, USA) [21]. Tukey's test was used $(p<0.05)$ to compare means.

\section{Results}

3.1. Morphophysiological Responses, Enzymatic Activity, and Mineral-Elemental Response in Seedlings, Due to the Inoculation of PGPR Associated with Distichlis Spicata

\subsubsection{Seedling Height (PTH)}

The statistical analysis of the variable height of tomato seedlings produced in the greenhouse at 40 days after sowing (DAS) showed a significant difference among treatments $(p \leq 0.05)$. It was observed that the best treatment was the nutrient solution (14), and second was inoculation by $P$. lini in a combined way (seed + foliar spray) (12). The treatments with the lowest values turned out to be distilled water (13). Likewise, between the treatments (14 vs. 12), there was a difference of $12.9 \%$, the latter exceeding treatment 13 by $67.2 \%$ (Table 3 ).

\subsubsection{Stem Diameter (SDM)}

A similar behavior to that observed in seedling height was observed in the stem diameter variable. It was observed that the best treatments were the nutrient solution (14) and the inoculation by P. lini in a combined way (seed + foliar spray) (12), without significant differences; between both of these treatments, there is a difference of $5.64 \%$. However, a significant difference $(p \leq 0.05)$ was shown with the remaining treatments. The treatments with the lowest values turned out to be distilled water (13) and treatment 
number 1 (B. paralicheniformis in seed inoculation). Likewise, between the treatments (12 vs. 1), there was a difference of $79.91 \%$ (Table 3 ).

Table 3. Comparison of means for morphophysiological responses in seedlings, due to the inoculation of PGPR associated with Distichlis spicata.

\begin{tabular}{|c|c|c|c|c|c|c|c|c|c|c|}
\hline \multirow{3}{*}{ Treatments } & PTH & SDM & RDV & LA & $\mathbf{R}$ & $\mathbf{L}$ & $S$ & $\mathbf{R}$ & $\mathbf{L}$ & $S$ \\
\hline & \multicolumn{4}{|c|}{ Tomato Seedlings } & \multicolumn{3}{|c|}{ Plant Fresh Weight } & \multicolumn{3}{|c|}{ Plant Dry Matter } \\
\hline & $\mathrm{cm}$ & $\mathrm{mm}$ & $\mathrm{cm}^{3}$ & $\mathrm{~cm}^{2}$ & & & & & & \\
\hline 1 & $9.45^{\mathrm{e}}$ & $1.87^{\mathrm{ef}}$ & $1.48^{\mathrm{f}}$ & $10.72^{b}$ & $0.65^{\text {ed }}$ & $0.32^{\mathrm{fe}}$ & $0.26^{\mathrm{d}}$ & $0.05^{\mathrm{bcd}}$ & $0.04^{\text {cdef }}$ & $0.02^{\mathrm{ed}}$ \\
\hline 2 & $10.62^{b c d}$ & $2.25^{b c}$ & $1.66^{\mathrm{de}}$ & $9.80^{\mathrm{b}}$ & $0.85^{\text {cde }}$ & $0.45^{\text {cde }}$ & $0.36^{\mathrm{cd}}$ & $0.03^{\mathrm{fe}}$ & $0.05^{\mathrm{abcd}}$ & $0.02^{\mathrm{ed}}$ \\
\hline 3 & $10.90^{b c}$ & $2.26^{b c}$ & $1.73^{\mathrm{cd}}$ & $8.51^{\mathrm{bcd}}$ & $1.17^{b c}$ & $0.473^{\mathrm{cd}}$ & $0.43^{\mathrm{bcd}}$ & $0.07^{\mathrm{a}}$ & $0.06^{\mathrm{ab}}$ & 0.02 ed \\
\hline 4 & 9.99 cde & 1.84 ef & $1.35^{\mathrm{g}}$ & $8.70^{\mathrm{bcd}}$ & $1.07^{\mathrm{bcd}}$ & $0.47^{\mathrm{cd}}$ & $0.46^{\mathrm{bcd}}$ & $0.07^{a b}$ & $0.04^{\text {bcde }}$ & $0.03^{b c d}$ \\
\hline 5 & $10.56^{\mathrm{bcd}}$ & $2.10^{\mathrm{cd}}$ & $1.61^{\mathrm{e}}$ & 7.84 bcde & $1.08^{\mathrm{bcd}}$ & $0.48^{\mathrm{bcd}}$ & $0.55^{b c}$ & $0.05^{\mathrm{bcd}}$ & 0.04 bcdef & $0.02^{\text {ed }}$ \\
\hline 6 & $10.93^{b c}$ & $2.18^{\mathrm{bcd}}$ & $1.83^{b c}$ & 7.44 bcde & $1.16^{\mathrm{bcd}}$ & $0.46^{\text {cde }}$ & $0.47^{\mathrm{bcd}}$ & $0.06^{\mathrm{abc}}$ & $0.06^{\mathrm{abc}}$ & $0.04^{b}$ \\
\hline 7 & 9.61 de & 2.01 ed & $1.23^{\mathrm{h}}$ & 4.99 ed & 0.80 cde & 0.40 def & $0.39 \mathrm{bcd}$ & 0.04 cde & $0.03^{\mathrm{efg}}$ & 0.02 ed \\
\hline 8 & 10.09 cde & $2.20^{\mathrm{bcd}}$ & $1.31^{\mathrm{gh}}$ & 7.62 bcde & 1.00 bcde & $0.56^{\mathrm{abc}}$ & $0.41 \mathrm{bcd}$ & 0.04 cde & 0.04 def & $0.03^{\mathrm{cd}}$ \\
\hline 9 & $10.46^{\text {cde }}$ & $2.30^{a b c}$ & $1.41 \mathrm{gf}$ & $10.57^{b}$ & 1.19 bc & $0.546^{\mathrm{abcd}}$ & $0.38^{\text {bcd }}$ & $0.05^{b c d}$ & $0.03^{\text {efg }}$ & $0.03^{b c d}$ \\
\hline 10 & $10.25^{\text {cde }}$ & $2.21 \mathrm{bcd}$ & $1.50^{f}$ & $5.18^{\text {cde }}$ & $0.86^{\text {cde }}$ & $0.41^{\text {cdef }}$ & $0.56^{b c}$ & 0.04 de & 0.04 cdef & $0.03^{b c d}$ \\
\hline 11 & $10.92^{b c}$ & $2.23^{b c}$ & $1.73^{\mathrm{cd}}$ & $9.36^{b c}$ & $1.91^{\mathrm{a}}$ & $0.62^{a b}$ & $0.85^{\mathrm{a}}$ & 0.04 de & 0.04 def & $0.03^{b c d}$ \\
\hline 12 & $11.61^{b}$ & $2.34^{\mathrm{ab}}$ & $1.96^{\mathrm{a}}$ & $9.94^{b}$ & $1.43^{\mathrm{ab}}$ & $0.54^{\mathrm{abcd}}$ & $0.46^{\mathrm{bcd}}$ & $0.04^{\text {de }}$ & 0.04 def & $0.04^{b c}$ \\
\hline 13 & $7.89^{\mathrm{f}}$ & $1.78^{\mathrm{f}}$ & $0.76^{\mathrm{i}}$ & $4.14^{\mathrm{e}}$ & $0.48^{\mathrm{e}}$ & $0.27767^{\mathrm{f}}$ & $0.27^{\mathrm{d}}$ & $0.02^{\mathrm{e}}$ & $0.02 \mathrm{~g}$ & $0.01^{\mathrm{e}}$ \\
\hline 14 & $13.33^{a}$ & $2.48^{\mathrm{a}}$ & $1.93^{a b}$ & $15.72^{\mathrm{a}}$ & $1.14^{\mathrm{bcd}}$ & $0.64^{\mathrm{a}}$ & $0.59^{b}$ & $0.06^{\mathrm{abcd}}$ & $0.07^{\mathrm{a}}$ & $0.06^{\mathrm{a}}$ \\
\hline
\end{tabular}

$\mathrm{PTH}=$ plant height; $\mathrm{SDM}=$ stem diameter; $\mathrm{RDV}=$ root displaced volume; $\mathrm{LA}=$ leaf area; $\mathrm{R}=$ root; $\mathrm{L}=$ leaf; and $\mathrm{S}=$ stem. $1=\mathrm{LB} 1$ * seed inoculation; $2=\mathrm{LB} 1 *$ seedling spray; $3=\mathrm{LB} 1 *$ both; $4=\mathrm{NFB} 2 *$ seed inoculation; $5=\mathrm{NFB2} *$ seedling spray; $6=\mathrm{NFB2} *$ both; $7=\mathrm{KB} 3$ * seed inoculation; $8=\mathrm{KB} 3 *$ seedling spray; $9=\mathrm{KB} 3 *$ both; $10=\mathrm{KB} 4{ }^{*}$ seed inoculation; $11=\mathrm{KB} 4$ * seedling spray; $12=\mathrm{KB} 4 *$ both; $13=\mathrm{DW} *$ irrigation; $14=\mathrm{NS} *$ irrigation. Different letters within indicate significant statistical differences (Tukey; $p \leq 0.05)$.

\subsubsection{Root Displaced Volume (RDV)}

In this variable, the inoculation was particularly evident when applied in combination with Pseudomonas lini (seed + foliar spray); compared with treatments 1 to 11, there existed differences with $p \leq 0.05$. We found that treatment number 12 exceeded treatment 1 by $61.22 \%$, and, although the Pseudomonas lini treatment (seed + foliar spray) performed better than treatment 14, there were no significant differences (Table 3).

\subsubsection{Leaf Area (LA)}

The statistical analysis of the leaf area at 40 DAS showed a highly significant difference between treatments. Nutritive solution (NS) showed better development, with leaf area $31.8 \%$ higher than seedlings treated with $B$. paralicheniformis in seed inoculation; however, among treatments inoculated, there were no significant differences, except with $A$. caviae and P. lini in inoculated seed. Moreover, it was observed that, among treatments, the best inoculation was using both forms (in seed and spraying seedling) (Table 3).

\subsubsection{Plant Fresh Weight and Plant Dry Matter}

Analysis results of the root, leaf, and stem fresh weight at 40 DAS in tomato seedlings inoculated with PGPR showed significant differences among treatments. It could be seen that, in each fresh weight organ evaluated (root $=\mathrm{R}$; leaf $=\mathrm{L}$; and stem $=\mathrm{S}$ ), treatment 11 ( $P$. lini inoculated as a spray form) stood out, while the most affected treatments were 7 and 13 in $R$, $\mathrm{L}$, and S (Table 3). On the other hand, in dry matter, the best treatment was inoculation with Bacillus paralicheniformis applied in the combination way (seed + foliar spray).

3.1.6. Enzymatic Activity-Nitrate Reductase Analysis: (1) Endogenous Reaction (ENDO), (2) Induced Reaction with $\mathrm{NO}_{3}-$ Substrate (NSB), (3) Reaction with Mo as Cofactor (CMO), and (4) Substrate and Cofactor $\mathrm{NO}_{3}{ }^{-}+\mathrm{Mo}(\mathrm{MNR})$

Regarding nitrate reductase, the endogenous reaction quantifies the contribution of nitrate naturally assimilated by the plant to later reduce it to nitrite. A highly significant difference was obtained between treatments; the greatest effects were in 1 to 5 , and 7 and 8 treatments, while, numerically, treatment 14 was the lowest. Bacillus paralicheniformis in 
seed inoculation showed $15.59 \%$ greater nitrate reduction than that of the treatment based on nutritive solution (Table 4 ).

Table 4. Comparison of means for nitrate reductase activity responses in seedlings, due to the inoculation of PGPR associated with Distichlis spicata.

\begin{tabular}{|c|c|c|c|c|}
\hline \multirow{2}{*}{ Treatments } & ENDO & NSB & CMO & MNR \\
\hline & \multicolumn{4}{|c|}{$\mu$ Moles $\mathrm{NO}_{2} / \mathrm{gpf} / \mathrm{h}$} \\
\hline 1 & $6.86^{\mathrm{a}}$ & $8.26^{b}$ & $70.85^{f}$ & $120.97 \mathrm{bc}$ \\
\hline 2 & $6.46^{\mathrm{abc}}$ & $36.89^{\mathrm{a}}$ & $80.57^{\text {cdef }}$ & $130.68^{a}$ \\
\hline 3 & $6.42^{\mathrm{abcd}}$ & $37.61^{\mathrm{a}}$ & $73.72^{f}$ & 109.57 de \\
\hline 4 & $6.68^{a b}$ & $35.06^{\mathrm{a}}$ & 77.10 def & $109.39 \mathrm{def}$ \\
\hline 5 & $6.59 a b c$ & $39.84^{\mathrm{a}}$ & $83.83^{\mathrm{cd}}$ & 101.78 fg \\
\hline 6 & 6.23 bcde & $7.72^{b}$ & 77.20 def & 108.44 defg \\
\hline 7 & $6.49^{a b c}$ & $38.61^{a}$ & $85.19^{b c}$ & $105.014^{\text {efg }}$ \\
\hline 8 & $6.46^{\mathrm{abc}}$ & $35.86^{\mathrm{a}}$ & 77.63 def & $130.18 \mathrm{a}$ \\
\hline 9 & 6.17 bcde & $35.92^{\mathrm{a}}$ & $94.62^{\mathrm{a}}$ & $100.84^{g}$ \\
\hline 10 & 6.23 bcde & $38.50^{\mathrm{a}}$ & $73.18^{\mathrm{f}}$ & $126.73^{\mathrm{ab}}$ \\
\hline 11 & 6.09 cde & $36.42^{\mathrm{a}}$ & $91.25^{\mathrm{ab}}$ & $128.53^{a b}$ \\
\hline 12 & $6.16^{\text {bcde }}$ & $39.78^{a}$ & 80.79 cde & $131.86^{\mathrm{a}}$ \\
\hline 13 & 5.93 de & $36.99^{\mathrm{a}}$ & $81.22 \mathrm{~cd}$ & $110.25^{\mathrm{de}}$ \\
\hline 14 & $5.79 \mathrm{e}$ & $34.76^{\mathrm{a}}$ & $81.75^{\mathrm{cd}}$ & $115.94^{\mathrm{cd}}$ \\
\hline
\end{tabular}

$\mathrm{ENDO}=$ endogenous reaction; $\mathrm{NSB}=$ induced reaction with $\mathrm{NO}_{3}{ }^{-}$substrate; $\mathrm{CMO}=$ reaction with $\mathrm{Mo}$ as a cofactor and $\mathrm{MNR}=$ substrate and cofactor $\left(\mathrm{NO}_{3}{ }^{-}+\mathrm{Mo}\right) .1=\mathrm{LB} 1$ * seed inoculation; $2=\mathrm{LB} 1$ * seedling spray; $3=\mathrm{LB} 1$ * both; $4=\mathrm{NFB} 2 *$ seed inoculation; $5=\mathrm{NFB} 2 *$ seedling spray; $6=\mathrm{NFB2} *$ both; $7=\mathrm{KB} 3{ }^{*}$ seed inoculation; $8=\mathrm{KB} 3 *$ seedling spray; $9=\mathrm{KB} 3$ * both; $10=\mathrm{KB} 4$ * seed inoculation; $11=\mathrm{KB} 4$ * seedling spray; $12=\mathrm{KB} 4$ * both; $13=\mathrm{DW}$ * irrigation; $14=\mathrm{NS} *$ irrigation. Different letters within indicate significant statistical differences (Tukey; $p \leq 0.05$ ).

According to the nitrate reductase enzyme, the reaction induced with $\mathrm{NO}_{3}{ }^{-}$as a substrate (NSB) quantifies the contribution of nitrate assimilated by the plant and subsequently reduced to nitrite. No significant differences were obtained in most of the treatments, except with Acinetobacter guillouiae and B. paralicheniformis using the two forms of inoculation (seed and spray form).

In the determination of the enzyme nitrate reductase in reaction with molybdenum as a cofactor (CMO), Mo serves as a bridge to bring the substrate and the enzyme together. In this case, it helps to make the reaction more stable for the NR enzyme. This quantifies the contribution of nitrate that the plant assimilates to later reduce it to nitrite. Analysis results showed variation and significant differences in treatments. Aeromonas caviae (9) was superior to other treatments, indicating that this strain in inoculation in seed and spray form works better with a cofactor that allows it to stabilize the reaction because it showed poorer endogenous results, or with the use of a substrate, in contrast to the other strains. The induced reaction of nitrate reductase with $\mathrm{Mo}$ as a cofactor and $\mathrm{NO}_{3}{ }^{-}$as a substrate for the NR enzyme quantifies the contribution of nitrate that the plant assimilates to later reduce it to nitrite. Notably, however, this reaction shows that, for $P$. lini inoculated in seed (treatment 10) to perform better, it requires more available nitrate and $\mathrm{Mo}$ as a reaction stabilizer.

In the reaction with substrate and cofactor $\left(\mathrm{NO}_{3-}+\mathrm{Mo}\right)(\mathrm{MNR})$, the results showed significant differences. The greatest effect was to the treatments 12, 8, and 2 (P. lini (AP + IS), A. caviae (AP), and Bacillus paralicheniformis (AP), respectively), while A. caviae (seed + foliar spray) was the lowest (treatment 9) (Table 4).

\subsubsection{Plant Tissue Elemental Analysis}

$\mathrm{N}$ is the most widely used nutrient in fertilizer because it is the most demanded for plant growth. When quantifying the total $\mathrm{N}$ content, a significant difference was found in treatments. The nutritive solution showed superior results, with $10.75 \%$ more nitrogen than the treatment based on P. lini with SP inoculation, and $49.8 \%$ more than treatment 7 , in which it was the lowest (Table 5). No significant differences among NS were noted with treatments $3,5,6,8,10$, and 11 . 
Table 5. Plant tissue mineral analysis under all treatments.

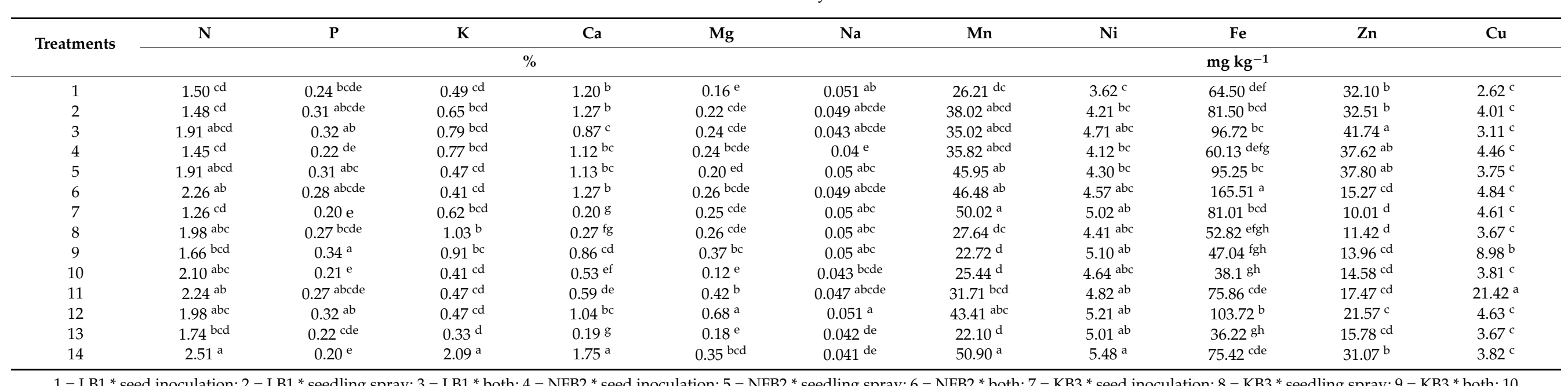

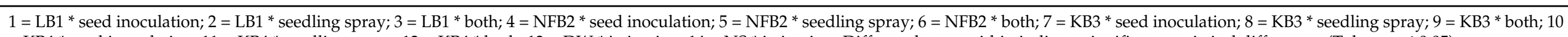
$=\mathrm{KB} 4{ }^{*}$ seed inoculation; $11=\mathrm{KB} 4 *$ seedling spray; $12=\mathrm{KB} 4 *$ both; $13=\mathrm{DW} *$ irrigation; $14=\mathrm{NS} *$ irrigation. Different letters within indicate significant statistical differences (Tukey; $p \leq 0.05$ ). 
$\mathrm{P}$ is an essential macro-element for plant growth. Phosphorus participates in metabolic processes, such as photosynthesis, energy and gene transfer, and the synthesis and degradation of carbohydrates [22]. The treatments with A. caviae (9), Bacillus paralicheniformis (3), and $P$. lini (12) were significantly superior to the nutritive solution and distilled water.

Potassium content showed a highly significant difference between the strains. Although the best treatment was with NS, it could be seen that the second-best treatment (8) was lower by $50.71 \%$, while, with DW (13), it was $84.21 \%$ (Table 5).

$\mathrm{Ca}$ is a vital constituent of the cell wall and, consequently, is essential for meristematic activity. A highly significant difference in calcium content was found between treatments. The NS treatment also behaved as the best for the Ca element with $p \leq 0.05$. Likewise, a similar behavior in the values was observed for treatments $1,2,4,5$, and 12 when the different strains were inoculated in seed and spray form (Table 5).

The nutritional analysis of magnesium in the present study indicates a significant difference in both factors and their interaction. The strain KB4 (Pseudomonas lini) was superior in a combined way (seed + foliar spray) (12) by 73.52\% compared with DW (Table 5).

The results for sodium concentration showed that there was a highly significant difference between strains, and the bacterial application mode results were statistically equal. Again, the strain KB4 (Pseudomonas lini) was superior in a combined way (seed + foliar spray) (12) (Table 5).

Manganese content showed a highly significant difference between treatments. The treatments with the highest values were the treatments NS, 7, 5, 6, 12, and 2 (Table 5). Among the treated strains, the best was Aeromonas caviae with seed inoculation, surpassing DW by $55.81 \%$ (Table 5 ).

Nickel content did not show a significant difference between treatments; however, numerically, the best was NS. Strains KB3 (Aeromonas caviae) and KB4 (Pseudomonas lini) showed the highest nickel content among bacteria. The nutrient solution showed $4.92 \%$ higher nickel than the strain KB4 (Pseudomonas lini), which was the strain that showed the highest value among bacteria (Table 5). In the form of application, the combined treatment in P. lini showed the best values.

A highly significant difference in Fe content was obtained among treatments. The highest amount of iron was found in the NFB2 strain in the combined application form, with $456 \%$ greater iron than DW, and 219.48\% greater iron than that of the nutrient solution (Table 5).

In terms of zinc mineral content, a significant difference was obtained between bacteria, and in the interaction of both factors. Higher values were found for the LB1 strain (Bacillus paralicheniformis) inoculated using the combined treatment. Zinc content was found to be $62.19 \%$ higher compared to the treatment of distilled water, and $25.56 \%$ higher compared to the nutrient solution (Table 5). Values for the form of application indicated that the mineral content of zinc was not affected by the form of application of the PGPR. Zinc is an important activating component of several enzymes involved in metabolic and biochemical activities.

A highly significant difference in copper content was obtained in the interaction of both factors. The strain KB4 (Pseudomonas lini) (11) in spray form showed better results when inoculated, with $82.86 \%$ more Cu content than that of the distilled water treatment, and $82.16 \%$ more than that of the nutritive solution (Table 5).

\subsubsection{Microbiological Analysis (CFU)}

In the microbiological count, a significant difference was found between the strains, the best treatments being the ones in which the strains NFB2 (Acinetobacter guillouiae), KB4 (Pseudomonas lini), and LB1 (Bacillus paralicheniformis) were applied. The opposite occurred for strain KB3 (Aeromonas caviae). Likewise, differences were also observed in comparison with the individual treatments (form of inoculation), which suggests that the combination of inoculations influences a greater number of growth-promoting microorganisms that favor biochemical and physiological variables, such as those evaluated in the present study (Figure 1). 


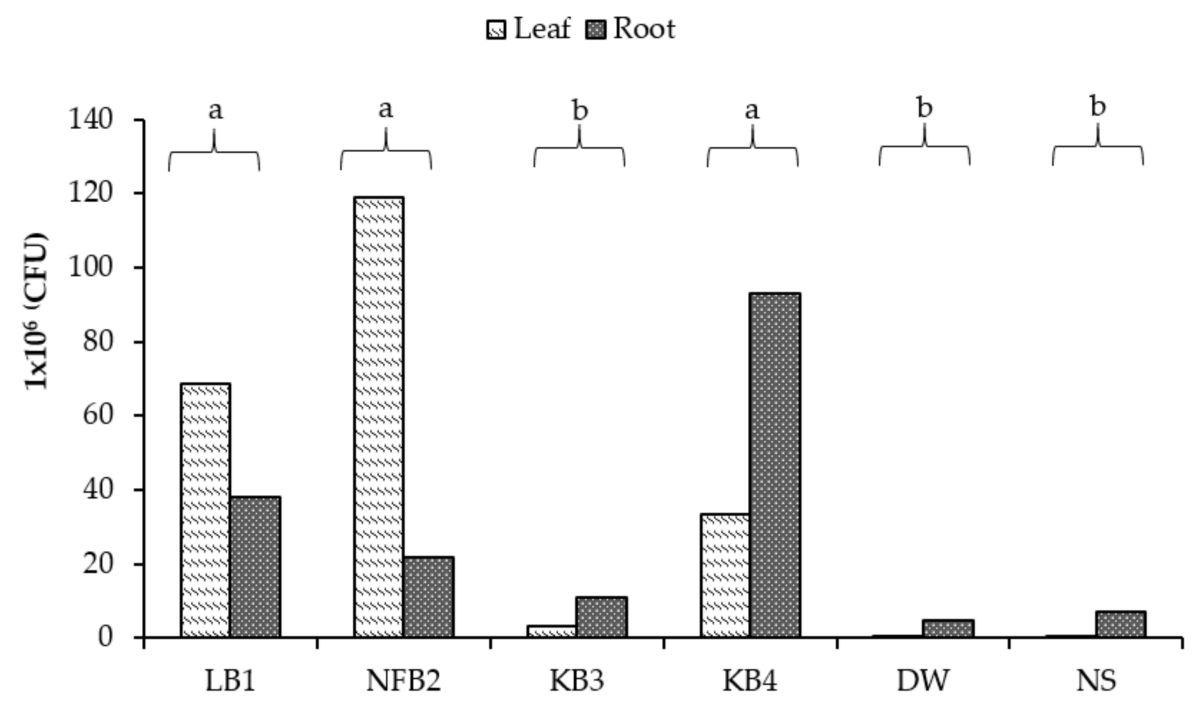

Figure 1. Comparison of means of colony-forming units (CFU) in $\times 10^{6}$ concentration of tomato seedlings produced in a greenhouse with different application methods of plant growth promoting rhizobacteria. LB1 = Bacillus paralicheniformis; NFB2 = Acinetobacter guillouiae; KB3 = Aeromona caviae; KB4 = Pseudomonas lini; DW = distilled water; NS = nutritive solution. Different letters above the brackets between each group of columns indicate significant statistical differences between treatments (Tukey; $p \leq 0.05$ ).

\section{Discussion}

According to the inoculation of the four bacteria, considering the types of inoculation in the seedling stage, the results obtained agree with [23-25] and, although the trials have been carried out with other plants and other beneficial microorganisms, some inhibit the effects on germination [26]. However, other studies show positive effects with this type of microorganism $[27,28]$ that also coincide with the results of the present study. The positive effects of these bacteria observed in the present study are apparently due to the production of substances like growth promoters, as reported in other studies [27-32]. Similar results were obtained by [33], in which significant differences, of up to $36 \%$, were obtained in the height of tomato seedlings inoculated with PGPR compared to the non-inoculated control. Differences were previously found in the diameter of the watermelon and melon stem with the inoculation of Pseudomonas fluorenses, obtaining values $20.6 \%$ higher than the diameter of the control without inoculation [34]. This result is consistent with the present investigation, in which the diameter of the KB4 strain was greater than that of distilled water. The results obtained in our study exceed those obtained by Zulueta-Rodriguez et al. [32]. Noh et al. [33] found a significant difference with the inoculation of rhizobacteria in tomato seedlings, which had a $42.2 \%$ greater root volume than that of the control without inoculation, which indicates that inoculation with KB4 exceeds the results obtained by the aforementioned author. Aguado-Santacruz et al. [34] note that some species of the genus Pseudomonas produce an enzyme called 1-aminocyclopropane-1-carboxylate deaminase; increasing the activity of this enzyme immediately decreases the plant's production of ethylene and, therefore, significantly increases the growth of the root. ZuluetaRodríguez et al. [32] obtained fresh weight values that were $49.56 \%$ lower for tomato seedlings inoculated with Pseudomonas putida. In combination with the values obtained in the present study, these results are not enough to indicate that Pseudomona strains increase the fresh weight of the seedling.

In addition, considering types of inoculation, Cisneros-Rojas et al. [35] identified similar values when inoculating coffee seedlings with a Bacillus strain, i.e., 59.70\% higher dry weight than that of the control without inoculating. When analyzing bacterial root exudate and zoglea, high levels of phosphorus were detected. These were attributed to the ability of the Bacillus bacteria to solubilize phosphates and create synergies with other 
bacteria, like availability of nutrients, reduction of toxicity due to toxic metals, changes in $\mathrm{pH}$, and production and / or stimulation of phytohormones, among others [35,36].

Espinosa et al. [37] mention that the application of Bacillus sp., combined with the use of a compost-based substrate, obtains large foliar areas. It is a good fertilization alternative for greenhouse tomato production, with an acceptable commercial quality and foliar areas. Rojas-Solís et al. [38] obtained similar and favorable results with Bacillus sp., compared with the strain Pseudomonas sp., in the growth promotion of tomato plants in a greenhouse. Although it is true that the present study was not conducted under salinity conditions, there are studies that show that plant growth can be promoted under these conditions, due to abilities such as reducing atmospheric nitrogen to ammonia (NF) through the synthesis of an enzymatic complex called nitrogenase [39].

The enzymatic activity of the plant is responsible for the formation of stable organic molecules that contribute to the stability of the physiology and biochemistry of the plant, and intervene in various cycles within it. Méndez-Gómez et al. [40] indicated that the positive effect of Bacillus paralicheniformis under a sprayed treatment is due to the relationship between nitric oxide and auxins at the beginning of the root development of seedlings; in metabolic pathways, nitric oxide and auxins are important for seedlings' growth. In various growth-promoting bacteria, nitric oxide can be produced under aerobic conditions and catalyzed in two ways, namely, via the enzyme nitrate reductase and the enzyme nitric oxide synthetase. Similarly, this positive effect on the plant caused by the LB1 strain (Bacillus paralicheniformis) via spraying occurs because LB1 is an aerobic bacterium and naturally induces the growth of seedlings. Coopens et al. [41] obtained a value of $0.14 \mu \mathrm{M}$ of $\mathrm{NO}_{2}{ }^{-} \mathrm{g} \mathrm{p} \mathrm{h} \mathrm{h}^{-1}$ from foliar application of microalgae to tomato seedlings in a greenhouse. However, this result was surpassed by that from the application of a Bacillus paralicheniformis strain via spraying, for which a value of $6.86 \mu \mathrm{M}$ of $\mathrm{NO}_{2}{ }^{-} \mathrm{g} \mathrm{p} \mathrm{fh}{ }^{-1}$ was obtained.

The phytochemical analysis, or analysis of plant tissue, usually refers to the chemical analysis of leaves (foliar), root, and stem, but it is an analysis applicable to any plant tissue (twigs, flowers, fruits, others); this diagnostic technique is widely recognized to determine nutrient concentrations and thereby assess the nutritional status of the plant species. According to our results in N content, Sánchez-López et al. [42] showed in their work that, using strains of the genus Pseudomonas, the plant growth of tomato plants improved, registering greater absorption of nutrients. These results agree with those of the present study, because the strain KB4 belongs to the genus Pseudomonas. Studies related to other biological sources, such as that of Coppens et al. [41], used microalgae via a sprinkled application to tomato seedlings in a greenhouse, obtaining highest values $(4.7 \%$ higher than the control) of nitrogen at 90 DAS. We consider that this difference in days could be overcome by Pseudomonas lini if the experiment had been extended for another 54 days. In addition to the results obtained with this nutrient in the present study, a significant difference was obtained in the application treatments. On the other hand, one of the most obvious effects of rhizobacteria in our study was observed in the increase in root mass, mainly in the number of secondary roots, which provides plants with a larger area for the absorption of water and nutrients. This is because PGPR can enhance plant growth by a wide variety of mechanisms, like phosphate solubilization, siderophore production, biological nitrogen fixation, rhizosphere engineering, production of 1-aminocyclopropane1-carboxylate deaminase (ACC), phytohormone production, exhibiting antifungal activity, production of volatile organic compounds (VOCs), induction of systemic resistance, etc. [43]. Although this test was not carried out in this study, recent studies have shown that PGPRs containing ACC deaminase induce the production of longer roots, increasing the absorption of water [44,45]. Ribaudo et al. [46] mentions that, from the study of the relationship between the presence of ACC deaminase activity in PGPR and the inhibitory effect of ethylene on it, a possible role of the enzyme in the PGPR/PGPR interaction mechanism has been proposed in plants. At the same time, [11] report an activity of the ACC deaminase enzyme of $91 \mu \mathrm{mol} \alpha-\mathrm{KB} / \mathrm{h} / \mathrm{mg}$ Pr of a PGPR isolated from the rhizosphere of $D$. spicata. 
In $\mathrm{P}, \mathrm{K}$, and $\mathrm{Ca}$ contents, our findings agree with $[22,47]$; in addition, same authors cited that potassium is an essential nutrient that is absorbed by plants in greater amounts than any other nutrient, except nitrogen. Unlike most other nutrients, potassium is not incorporated into structures of organic compounds. Instead, potassium remains in an ionic form $\left(\mathrm{K}^{+}\right)$in solution and acts as an activator of many enzymatic reactions in the cell [47]. $\mathrm{K}$ is involved in functions in nutrition and plant growth that influence quality. These include the regulation of metabolic processes, such as photosynthesis, and activation of enzymes that metabolize carbohydrates for the synthesis of amino acids and proteins, and facilitate cell division and growth by helping to move starches and sugars between parts of the plant [22]. With this in mind, our results agree with those of Azfal et al. [8] and Fukami et al. [48], when evaluating inoculation forms in nightshade plants.

In $\mathrm{Mg}, \mathrm{Na}$, and $\mathrm{Mn}$ content, our findings are similar to Azfal et al. [8], which indicates that a combination of inoculation, either to seed, substrate, or foliar spraying, was found to be favorable because the magnesium content in plants is favored by PGPR. The bestknown role of magnesium $(\mathrm{Mg})$ in plants is its presence in the center of the chlorophyll molecule as a structural component of ribosomes and, for this reason, it is essential for photosynthesis. It is also involved in protein metabolism and is required for the maximum activity of almost all phosphorylating enzymes in carbohydrate metabolism [22], while in $\mathrm{Na}$, the same authors [22] indicate that, when solanaceous glycophytes are influenced by PGPR, they show a certain tolerance to salinity that may exist in the soil solution or substrate, minimizing the osmotic or ionic effect on phenological variables, such as height, displaced root volume, leaf area, biomass, and dry matter, among others. Furthermore, sodium stimulates cell elongation growth and can replace potassium as an osmotically active solute, although, in excess, it seriously affects plant development $[49,50]$. According to Mn content, our findings agree with Shao et al. [50]. Moreover, they indicated that manganese acts as an activator of essential enzymes in growth processes, supports iron in the formation of chlorophyll, accelerates germination and maturation, and increases the use of calcium, magnesium, and phosphorus. The participation of $\mathrm{Mn}$ is mainly in the young parts of the plant, which are often the richest in Mn [50].

In $\mathrm{Ni}, \mathrm{Fe}, \mathrm{Zn}$, and $\mathrm{Cu}$ analysis, our results showed that nickel (Ni) is actively absorbed through the plasmalemma in ionic form as $\mathrm{Ni}^{++}$. This element is essential for the function of the enzyme urease, which is important in the transformation of $\mathrm{N}$ [51,52]; Fe is a component of the enzymatic system that is present in oxidation-reduction reactions in the plant, and regulates respiration, photosynthesis, and reduction of nitrates and sulfates [22]. These activities are favored when the participation of PGPR occurs in plants, benefiting Zn as a functional, structural, or regulatory cofactor of a large number of enzymes, and playing an essential role in DNA transcription [53]. In participation with beneficial bacteria, zinc also performs the function of catalyzing the oxidation process in plant cells. In addition, it is vital for the transformation of carbohydrates and influences the formation of chlorophyll and auxins as growth-promoting compounds [54].

At the end of the experiments (40 days after sowing (DAS)) and a microbiological analysis considering the results, Peña et al. [55] indicates that this reduced CFU content may not be due to the incompatibility of the microorganism with the plant, but may be because of its property of slower growth. Currently, some methods are used to inoculate bacteria; the simplest is applying the bacteria in liquid suspension, either directly to the soil or to the seeds, or in a sprinkled way. However, there are others that should be evaluated and in different conditions (greenhouse and field) [56].

The results related to increases in the variables evaluated, under the given conditions and due to the beneficial effect of the bacteria studied in the tomato seedlings, suggest the possibility of using them at this stage. However, further research is needed on the fate of the inoculations in tomato so, in this sense, it is desirable to conduct complementary studies on this plant resource and its interaction with beneficial rhizobacteria. 


\section{Conclusions}

Currently, sustainable sources are being sought in agriculture to displace the use of chemicals and improve yields. In the present study, the inoculation of Bacillus paralicheniformis, Acinetobacter guillouiae, Aeromona caviae, and Pseudomonas lini, compared with distilled water and nutritive solution in tomato seed, combined with a sprinkling in the seedling stage, in comparison with the control treatments (distilled water and nutrient solution), showed superior results in the enzymatic, morphophysiological, and nitrate reductase variables. In the elemental analysis of plant tissue, the results were variable, highlighting the combined form of inoculation for the bacteria. In particular, the results of the study allowed the highlighting of Pseudomonas lini and Bacillus paralicheniformis, especially when they were inoculated in a combined way (inoculation in seed and sprayed forms). However, studies related to the promotion of plants of the subsequent phenological stages of tomato should be considered in further studies.

Author Contributions: Conceptualization, P.P.R., E.L.F., E.O.R.-P., and T.J.Á.C.-V.; methodology, T.J.Á.C.-V., A.A.V.-G., E.L.F., and M.G.C.-V.; software, P.P.R. and T.L.G.-S.; validation, E.L.F., T.J.Á.C.V., E.O.R.-P., and P.P.R.; formal analysis, P.P.R., E.O.R.-P., E.L.F., and T.J.Á.C.-V.; investigation, E.O.R.P., A.A.V.-G., and M.G.C.-V.; data curation and analysis, P.P.R., E.O.R.-P., and E.L.F.; writing-original draft preparation, E.O.R.-P., P.P.R., T.J.Á.C.-V., and A.A.V.-G.; writing-review and editing, E.O.R.-P.; visualization, E.O.R.-P. All authors have read and agreed to the published version of the manuscript.

Funding: This research has received no external funding.

Informed Consent Statement: Not applicable.

Data Availability Statement: Not applicable.

Acknowledgments: We thank the National Technological Institute of Mexico-Campus Instituto Tecnologico de Torreon, for the use of the facilities granted. The authors are grateful for the technical assistance of the Water and Soil Analysis Laboratory technicians of Facultad de Agronomía y Zootecnia de la Universidad Juarez del Estado de Durango (UJED). Furthermore, we thank Dr. Jorge Sáenz-Mata, team leader of the Microbial Ecology Laboratory (UJED) for providing us with the PGPR.

Conflicts of Interest: The authors declare no conflict of interest of any kind; the funders had no role in the design and implementation of this research and its data interpretation, or in the decision to write and submit this manuscript.

\section{References}

1. FAOSTAT, Food and Agriculture Organization Corporate Statistical Database. Available online: http://www.fao.org/faostat/es/ \#data/QC (accessed on 9 January 2021).

2. SIAP-SAGARPA. Servicio de Información Agroalimentaria y Pesquera-Secretaria de Agricultura, Ganadería, Desarrollo Rural, Pesca y Alimentación. Available online: http://infosiap.siap.gob.mx/aagricola_siap_gb/ientidad/index.jsp (accessed on 25 January 2021).

3. Diver, S.; Greer, L. Sustainable Small-Scale Nursery Production; National Center for Appropriate Technology: Butte, MT, USA, 2008; p. 28. Available online: http://www.microfarms.com/technical/greenhousecd/greenhouse/nursery/nursery.pdf (accessed on 10 March 2021).

4. Grageda-Cabrera, O.A.; Díaz-Franco, A.; Peña-Cabriales, J.J.; Vera-Nuñez, J.A. Impacto de los biofertilizantes en la agricultura. Rev. Mex. Cienc. Agríc. 2012, 3, 1261-1274. [CrossRef]

5. Escobar, C.; Horna, Y.; Carreño, C.; Mendoza, G. Caracterización de cepas nativas de Azotobacter spp. y su efecto en el desarrollo de Lycopersicon esculentum Mill. "tomate" en Lambayeque. Sci. Agropecu. 2011, 2, 39-49. [CrossRef]

6. Armenta-Bojórquez, A.D.; García-Gutiérrez, C.; Camacho-Báez, J.R.; Apodaca-Sánchez, M.Á.; Gerardo-Montoya, L.; Nava-Pérez, E. Biofertilizantes en el desarrollo agrícola de México. Ra Ximhai 2010, 6, 51-56. [CrossRef]

7. Lara, C.; Avila, L.; Peñata, J. Native phosphate solubilizing bacteria to increase the crops in the department of Cordova-Colombia. Biotecnol. Sect. Agropecu. Agroind. 2011, 9, 114-120.

8. Afzal, M.; Yousaf, S.; Reichenauer, T.G.; Sessitsch, A. The Inoculation Method Affects Colonization and Performance of Bacterial Inoculant Strains in the Phytoremediation of Soil Contaminated with Diesel Oil. Int. J. Phytoremediat. 2012, 14, 35-47. [CrossRef]

9. Jasso, C.C.; Martínez, G.M.A.; Chávez, V.J.R.; Ramírez, T.J.A.; Garza, E. Guía Para Cultivar Jitomate en Condiciones de Malla Sombra en San Luís Potosí; Folleto técnico: SAGARPA, Mexico. 2012, pp. 9-54. Available online: http://www.inifapcirne.gob. $\mathrm{mx} /$ Biblioteca/Publicaciones/905.pdf (accessed on 12 January 2021). 
10. Carrillo, A.; Puente, M.; Castellanos, T.; Bashan, Y. Aplicaciones Biotecnologicas de Ecología Microbiana. Manual de Laboratorio Pontificia Universidad Javeriana; Centro de Investigaciones Biológicas del Noroeste: La Paz, Baja California Sur, Mexico, 1998 ; p. 51.

11. Palacio-Rodríguez, R.; Coria-Arellano, J.L.; López-Bucio, J.; Sánchez-Salas, J.; Muro-Pérez, G.; Castañeda-Gaytán, G.; Sáenz-Mata, J. Halophilic rhizobacteria from Distichlis spicata promote growth and improve salt tolerance in heterologous plant hosts. Symbiosis 2017, 73, 179-189. [CrossRef]

12. Richards, L.A. Diagnosis and Improvement of Saline and Alkali Soils; U.S. Department Agriculture Handbook 60: Washington, DC, USA, 1954.

13. Santamaría-César, J.; Figueroa-Viramontes, U.; Medina-Morales, M.d.C. Productividad de la alfalfa en condiciones de salinidad en el Distrito de Riego 017, Comarca Lagunera. Terra Latinoam. 2004, 22, 343-349.

14. Jaworski, E.G. Nitrate reductase assay in intact plant tissues. Biochem. Biophys. Res. Commun. 1971, 43, 1274-1279. [CrossRef]

15. Mauriño, S.G.; Echevarria, C.; Mejias, J.A.; Vargas, M.A.; Maldonado, J.M. Properties of the in vivo Nitrate Reductase Assay in Maize, Soybean, and Spinach Leaves. J. Plant Physiol. 1986, 124, 123-130. [CrossRef]

16. Hageman, R.H.; Hucklesby, D.P. Nitrate reductase from higher plants. In Methods in Enzymology; Academic Press: Cambridge, MA, USA, 1971; Volume 23, pp. 491-503.

17. Fernández, V.; Del Río, V.; Abadía, J.; Abadía, A. Foliar Iron Fertilization of Peach (Prunus persica L.) Batsch: Effects of Iron Compounds, Surfactants and Other Adjuvants. Plant Soil 2006, 289, 239-252. [CrossRef]

18. Wacal, C.; Ogata, N.; Basalirwa, D.; Handa, T.; Sasagawa, D.; Acidri, R.; Ishigaki, T.; Kato, M.; Masunaga, T.; Yamamoto, S.; et al Growth, Seed Yield, Mineral Nutrients and Soil Properties of Sesame (Sesamum indicum L.) as Influenced by Biochar Addition on Upland Field Converted from Paddy. Agronomy 2019, 9, 55. [CrossRef]

19. Helrich, K. Official Methods of Analysis of the Association of Official Analytical Chemists, 15th ed.; Arlington, VA Association of Official Analytical Chemists United States: Arlington, VA, USA, 1990; pp. 40-49.

20. Bertani, G. Studies on lysogenesis. I. The mode of phage liberation by lysogenic Escherichia coli. J. Bacteriol. 1951, 62, 293-300. [CrossRef] [PubMed]

21. SAS (Statistical Analysis System). SAS/STAT 9.2 User's Guide; SAS: Cary, NC, USA, 2016; Available online: https:/ / support.sas $\mathrm{com} /$ documentation/cdl/en/statugintroduction/61750/PDF/default/statugintroduction.pdf (accessed on 10 January 2021).

22. Nira, K. A review of effects of nutrient elements on crop quality. African Journal of Food, Agriculture. Nutr. Dev. 2015, 15, 9777-9783.

23. Puente, M.E.; Holguin, G.; Glick, B.R.; Bashan, Y. Root-surface colonization of black mangrove seedlings by Azospirillum halopraeferens and Azospirillum brasilense in seawater. FEMS Microbiol. Ecol. 1999, 29, 283-292. [CrossRef]

24. Rozema, J. The influence of salinity, inundation and temperature on the germination of some halophytes and non-halophytes. Oecol. Plant 1995, 10, 341.

25. Goodfriend, W.L.; Olsen, M.W.; Frye, R.J. Soil microfloral and microfaunal response to Salicornia bigelovii planting density and soil residue amendment. Plant Soil 2000, 223, 23-32. [CrossRef]

26. Díaz-Vargas, P.; Ferrera-Cerrato, R.; Almaraz-Suárez, J.J.; Alcántar-González, G. Inoculación de bacterias promotoras de crecimiento en lechuga. Terra Latinoam. 2001, 19, 327-335.

27. Arsac, J.F.; Lamothe, C.; Mulard, D.; Fages, J. Growth enhancement of maize (Zea mays L.) through Azospirillum lipoferum inoculation: Effect of plant genotype and bacterial concentration. Agronomie 1990, 10, 640-654. [CrossRef]

28. Puente, M.; Bashan, Y.J.S. Effect of Inoculation with Azospirillum brasilense Strains on the Germination and Seedlings Growth of the Giant Columnar Cardon Cactus (Pachycereus pringlei). Symbiosis 1993, 15, 49-60.

29. Haahtela, K.; Ronkko, R.; Laaskso, T.; Williams, P.; Korhonen, T. Root-associated Enterobacter and Klebsiella in Poa pratensis: Characterization of an iron-scavening system and a subtance stimulating root hair production. Mol. Plant Microbe Interact. 1990, 3 , 358-365. [CrossRef]

30. Turyanitsa, A.; Petak, A.; Nichik, M.; Petrosova, V. Capacity of Klebsiella bacteria to fix atmospheric nitrogen and to produce plant growth hormones. Mikrobiol 1995, 57, 28-34.

31. El-Khawas, H.; Adachi, K. Identification and quantification of auxins in culture media of Azospirillum and Klebsiella and their effect on rice roots. Biol. Fertil. Soils 1999, 28, 377-381. [CrossRef]

32. Zulueta, R.; Hernandez-Montiel, L.G.; Amador, B.; Rueda-Puente, E.; Capistrán, L.; Guez, E.; Cordoba, M.; Yu, F.-H.; Jokela, E. Effect of Hydropriming and Biopriming on Seed Germination and Growth of Two Mexican Fir Tree Species in Danger of Extinction. Forests 2015, 6, 3109-3122. [CrossRef]

33. Noh Medina, J.; Yam Chimal, C.; Borges Gómez, L.; Zúñiga Aguilar, J.J.; Godoy Hernández, G. Aislados bacterianos con potencial biofertilizante para plántulas de tomate. Terra Latinoam. 2014, 32, 273-281.

34. Aguado-Santacruz, G.; Moreno-Gómez, B.; Jimenez, B.; Moya, E.; Preciado, E. Impact of the microbial siderophores and phytosiderophores on the iron assimilation by plants: A synthesis. Rev. Fitotec. Mex. 2012, 35, 9-21.

35. Cisneros-Rojas, C.A.; Sánchez-de Prager, M.; Menjivar-Flores, J.C. Efecto de bacterias solubilizadoras de fosfatos sobre el desarrollo de plántulas de café. Agron. Mesoam. 2017, 28, 149-158. [CrossRef]

36. El-Shatnawi, M.K.J.; Makhadmeh, I.M. Ecophysiology of the Plant-Rhizosphere System. J. Agron. Crop Sci. 2001, 187, 1-9. [CrossRef] 
37. Espinosa Palomeque, B.; Moreno Reséndez, A.; Cano Ríos, P.; Álvarez Reyna, V.d.P.; Sáenz Mata, J.; Sánchez Galván, H.; González Rodríguez, G. Inoculación de rizobacterias promotoras del crecimiento vegetal en tomate (Solanum lycopersicum L.) cv. afrodita en invernadero. Terra Latinoam. 2017, 35, 169-178. [CrossRef]

38. Rojas-Solís, D.; Hernández-Pacheco, C.E.; Santoyo, G. Evaluation of Bacillus and Pseudomonas to colonize the rhizosphere and their effect on growth promotion in tomato (Physalis ixocarpa Brot. ex Horm.). Revista Chapingo. Ser. Hortic. 2016, 22, 45-58.

39. Geisseler, D.; Horwath, W.R.; Joergensen, R.G.; Ludwig, B. Pathways of nitrogen utilization by soil microorganisms-A review. Soil Biol. Biochem. 2010, 42, 2058-2067. [CrossRef]

40. Méndez-Gómez, M.; Castro-Mercado, E.; García-Pineda, E. Azospirillum una rizobacteria con uso potencial en la agricultura. Biológicas 2014, 16, 11-18.

41. Coppens, J.; Grunert, O.; van den Hende, S.; Vanhoutte, I.; Boon, N.; Haesaert, G.; Gelder, L. The use of microalgae as a high-value organic slow-release fertilizer results in tomatoes with increased carotenoid and sugar levels. J. Appl. Phycol. 2016, 28. [CrossRef]

42. Sánchez-López, D.B.; Gómez-Vargas, R.M.; Garrido Rubiano, M.F.; Bonilla Buitrago, R.R. Inoculación con bacterias promotoras de crecimiento vegetal en tomate bajo condiciones de invernadero. Rev. Mex. Cienc. Agríc. 2012, 3, 1401-1415.

43. Bhattacharyya, P.N.; Jha, D.K. Plant growth-promoting rhizobacteria (PGPR): Emergence in agriculture. World J. Microbiol. Biotechnol. 2012, 28, 1327-1350. [CrossRef] [PubMed]

44. Zahir, Z.A.; Arshad, M.; Frankenberger, W.T. Plant Growth Promoting Rhizobacteria: Applications and Perspectives in Agriculture. In Advances in Agronomy; Academic Press: Cambridge, MA, USA, 2003; Volume 81, pp. 97-168.

45. Esquivel-Cote, R.; Ramírez-Gama, R.M.; Tsuzuki-Reyes, G.; Orozco-Segovia, A.; Huante, P. Azospirillum lipoferum strain AZm5 containing 1-aminocyclopropane-1-carboxylic acid deaminase improves early growth of tomato seedlings under nitrogen deficiency. Plant Soil 2010, 337, 65-75. [CrossRef]

46. Ribaudo, C.M. Mecanismos Bioquímicos y Moleculares Desencadenados en la Interacción Bacterias Promotoras de Crecimiento Vegetal y Plantas de Interés Agronómico. Ph.D. Thesis, Universidad de Buenos Aires, Facultad de Ciencias Exactas y Naturales, Buenos Aires, Argentina, 2003. Available online: http:/ /hdl.handle.net/20.500.12110/tesis_n5372_Ribaudo (accessed on 17 April 2021).

47. Halvin, J.L.; Beaton, J.; Tisdale, S.; Nelson, W. Soil fertility and fertilizers: An Introduction to Nutrient Management; Pearson: Upper Saddle River, NJ, USA, 2005.

48. Fukami, J.; Nogueira, M.; Araujo, R.; Hungria, M. Accessing inoculation methods of maize and wheat with Azospirillum brasilense. AMB Express 2016, 6, 3. [CrossRef] [PubMed]

49. Hnilickova, H.; Hnilička, F.; Orsák, M.; Hejnak, V. Effect of salt stress on growth, electrolyte leakage, $\mathrm{Na}^{+}$and $\mathrm{K}^{+}$content in selected plant species. Plant Soil Environ. 2019, 65. [CrossRef]

50. Shao, J.F.; Yamaji, N.; Shen, R.F.; Ma, J.F. The Key to Mn Homeostasis in Plants: Regulation of Mn Transporters. Trends Plant Sci. 2017, 22, 215-224. [CrossRef]

51. Brown, P.H.; Welch, R.M.; Cary, E.E.; Checkai, R.T. Micronutrients. J. Plant Nutr. 1987, 10, 2125-2135. [CrossRef]

52. Rodríguez-Jiménez, T.; Ojeda-Barrios, D.; Blanco-Macías, F.; Valdez-Cepeda, R.; Parra-Quezada, R. Ureasa y níquel en la fisiología de las plantas. Rev. Chapingo Ser. Hortic. 2016, 22, 69-81. [CrossRef]

53. Liu, D.-Y.; Liu, Y.-M.; Zhang, W.; Chen, X.-P.; Zou, C.-Q. Zinc Uptake, Translocation, and Remobilization in Winter Wheat as Affected by Soil Application of Zn Fertilizer. Front. Plant Sci. 2019, 10. [CrossRef]

54. Muthukumararaja, T.M.; Sriramachandrasekharan, M.V. Effect of zinc on yield, zinc nutrition and zinc use efficiency of lowland rice. Int. J. Agric. Technol. 2012, 8, 551-561.

55. Peña, H.; Medina-Hernandez, D.; Ghasemi, M.; Rueda-Puente, E. Salt tolerant plants as a valuable resource for sustainable food production in arid and saline coastal zones. Acta Biol. Colomb. 2020, 26. [CrossRef]

56. Fages, J. An industrial view of Azospirillum inoculants: Formulation and application technology. Symbiosis 1992, 13, 15-26. 